\title{
Intellectual Capital, Corporate Culture and Performance of Firms Listed on Nairobi Securities Exchange
}

\author{
Anne Kariuki, Kellen Kiambati \\ Karatina University, Karatina, Kenya
}

The broad objective of this study was to establish the moderating effect of corporate culture on the relationship between intellectual capital and organizational performance of firms listed on Nairobi Securities Exchange. The review of literature provided conceptual and empirical gaps that formed the basis of the conceptual hypotheses. Two hypotheses were deduced from general objective: Intellectual capital has a significant influence on corporate performance; corporate culture moderates the relationship between intellectual capital and corporate performance. A cross-section research design was adopted. A survey questionnaire was the main tool of data collection and was distributed to the 50 heads of human resource departments in the different firms' period covering four financial years from 2009 to 2012. The study also utilized secondary data obtained from Capital Market Authority Statistical bulletins and Nairobi Securities Exchange Handbook 2012-2013 to collect data on financial performance (ROA, ROE, and Dividend Yield). Data were tested for reliability results showing that study dimensions were reliable, apart from task-oriented culture that had a Cronbach alpha of 0.262 , thus being not considered for further analysis; thus the study relied on employee-oriented culture as a measure of corporate culture. The hypotheses were tested using multiple regression analysis and hierarchical regression respectively. Multiple regression analysis showed that intellectual capital had a significant influence on non-financial performance and no significant influence on financial measures of performance (ROA, ROE, and Dividend Yield). Test for moderation showed that the interaction term was not significant and thus, employee-oriented culture did not moderate the relationship between intellectual capital and corporate performance. The study demonstrates importance of the influence of intellectual capital on non-financial performance of firms listed on Nairobi Securities Exchange. The results show that interplay among human capital, social capital, and organization capital is important for firms listed on Nairobi Securities Exchange and that the firms should nurture the employees into sharing their knowledge by creating internal and external networks and also creating support system within the organization to retain the knowledge.

Keywords: intellectual capital, corporate culture, employee-oriented culture, task-oriented, corporate performance

\section{Introduction}

In the face of intense globalized competition, there is a widespread recognition that intellectual capital is a critical force that drives economic growth (Huang \& Liu, 2005). Research on intellectual capital has given prominence to human resources as an invisible asset that creates value when embedded in the operations system

Anne Kariuki, Dr., Ph.D. in Business Administration, Karatina University, Kenya.

Kellen Kiambati, Dr., Ph.D. in Business Administration, Karatina University, Kenya.

Correspondence concerning this paper should be addressed to Anne Kariuki, Karatina University, P.O. Box 1957-10101, Karatina, Kenya. 
in a manner that enhances firm's ability to deal with turbulent environment. Intellectual capital and its importance as a driver of performance have been a recurring phase in Strategic and Human Resource Management (SHRM) and formed a main task of the executive agenda driven by the fact that intellectual capital has frequently been identified as an intangible source of competitive advantage (Bontis, 1996; Edvinnson \& Malone, 1997; J. Roos \& G. Roos, 1997).

Nevertheless, despite widespread belief held by academicians and practitioners that intellectual capital has a significant influence on corporate performance, empirical evidence from management research supporting the proposition has presented inconsistent findings. The inconsistent nature of the results motivated some scholars to investigate other possible explanations for divergence in findings. There are various reasons that have been advanced including methodological flaws, confusion and inconsistencies in conceptualization of the concept of intellectual capital, use of uni-dimensional nature of intellectual (Bontis, 1999; Kariuki, 2014; Kariuki, K'Obonyo \& Ogutu, 2014).

The majority of the studies that have investigated the existence of a relationship between intellectual capital and performance have assumed the existence of a direct relationship. This approach reflects a simplified assumption about how intellectual capital influences corporate performance and a general weakness in human resource management research. This implies that there is little or no fluctuation in level of influence of intellectual capital on corporate performance and that the internal or external environment cannot amplify or reduce the influence of intellectual capital. Becker and Gerhart (1996, p. 781) in their review of human resources practices and organization performance concluded that "the mechanisms by which human resource decision creates and sustains value are complicated and not well understood". In this regard a realistic view has been proposed that the influence of intellectual capital on corporate performance differs as a result of inner environment. Recent research suggests that there could be other factors that affect the relationship. For instance, Chaminade and Johanson (2003) and Cabrita and Bontis (2008) opine that corporate culture moderates the relationship between intellectual capital and corporate performance.

K'Obonyo and Dimba (2007) asserted that identifying existence of cultural values should be an empirical question not a prior assumption. Child (1981) asserted that culture has a moderating effect on organizations and noted that culturally driven preferences influence the exercise of choice between alternative practices. Chaminade and Johanson (2003) and Rikowski (2007) cite culture as an important organization attribute in intellectual capital management. They postulate that companies should create a culture of commitment through building of multi-dimensional relationships that lead to cooperation and collaboration rather than compliance. Beyond intellectual capital, studies point to the fact that inner environment of an organization is an important determinant of performance (Nyambegera, Daniels, \& Sparrow, 2001). The study proposes that corporate culture has a moderating effect on the relationship between intellectual capital and corporate performance of firms listed on Nairobi Securities Exchange (NSE).

Listed firms around the world are major drivers of major economies in the world. Firms listed on NSE are important to national competitiveness and play a leading role in economic development. Intense competition, government policies, and international rationalization have forced some of the corporations to close their operations and relocate to other parts of the world. The context in which firms operate differs in terms of culture, economic policies, politics, and government policies. Firms listed on NSE are both domestically and foreign owned and for foreign firms they combine national culture of their home countries with that of local countries to a hybrid of corporate culture that influences the operations and subsequent performance. This study 
extends earlier research concerning the relationship between intellectual capital and corporate performance with particular emphasis on moderating effect of corporate culture. Given, the intense globalized competition, there is a widespread recognition that intellectual capital is a driver of performance and has been a recurring phase in strategic and human resource management. However, despite the importance attributed to intellectual capital and performance, variability, and inconsistencies in previous results, this study stands out as it attempts to answer the question: does corporate culture moderate the relationship between intellectual capital and performance?

The remainder of the paper proceeds as follows: First, literature review is presented, to clarify the notion of intellectual capital, corporate culture and performance followed by analysis of empirical literature. Second, the methodology of the study is presented followed by analysis and discussion of results. Lastly, the conclusion is deduced from the results findings and suggestion for future studies is presented.

\section{Literature Review}

This section presents a detailed description of the concepts of intellectual capital, corporate culture, and corporate performance. The section also covers literature review on the relationship between intellectual capital and performance; moderating effect of corporate reputation on the relationship between intellectual capital and performance with the aim of revealing the knowledge gaps.

\section{The Concept of Intellectual Capital}

The concept of intellectual capital surfaced in 1990s (Bontis, 1996) and has received varying degree of attention from diverse discipline within business management especially in human resource management and strategic management. Intellectual capital is a broad-based term considered synonymous with a firm's intangible asset. Youndat, Subramanian, and Snell (2004) note that several writers have presented frameworks to help conceptualize the construct and make it easier to operationalize the research. Edvinsson and Malone (1997) posit that intellectual capital comprises human capital and structural capital. Structural capital is subdivided into organization capital and customer capital. Stewart (1997) similarly categorizes intellectual capital as human capital and structural capital but introduces customer capital as a sub-category. Bontis (1996) introduces relational capital as an expanded version of customer capital. Youndat et al. (2004) and Wright, Dunford, and Snell (2001) introduced social capital and organizational capital. Despite variety of conceptualization, there is consensus that intellectual capital is a multidimensional concept and drawing from the work of Wright et al. (2001) and Youndat et al. (2004), from which we propose the constructs of human capital, social capital, and organizational capital. The choice of measures was based on the reliability and validity of scales used in different studies.

Human capital refers to the acquired skills, knowledge, and abilities held by individuals and obtained through their education; training and experience are often cited as an intangible asset that differentiates financial performance among firms (Hitt, Bierman, Shimuzu, \& Kochar, 2001). Becker (1993) defined human capital as the knowledge, information, ideas, and skills of individuals. Becker and Gerhart (1996) defined human capital as knowledge, skills, health, or values that unlike physical and financial capital cannot be separated from persons who own it. OECD (1998) defined human capital as knowledge, skills, competence, and attributes embodied in individual that are relevant to economic activity. In addition, Hatch and Dyer (2004) suggest that human capital reflects knowledge and skills embodied in people. Similar to Bontis's (1998) 
perspectives, human capital requires the support of organization capital and social capital (Youndat et al., 2004).

Nahapiet and Ghoshal (1998) defined social capital as the sum of actual or potential resources embedded within and available through network of relationship possessed or developed by individuals or social units. Bontis (1996) used the term customer capital to capture the concept of relational capital (J. Roos, G. Roos, Dragonetti, \& Edvinsson, 1997). His view is similar to what is referred to as external social capital by management theorist (Nahapiet \& Goshal, 1998). Roos et al. (1997) used the concept external capital, while Stewart (1997) used alliance capital. Drawing from the RBV of the firm, Nahapiet and Ghoshal (1998) observed that social capital is a source of competitive advantage, because of its tactiness, path dependence, and social complexity.

Youndat et al. (2004) proposed that organizational capital as compared to structural capital is important in studying intellectual capital because it is capital that is owned by the organization. Stewart (1997) defined organization capital as an institutionalized knowledge and codified experience stored in organization memory devices including operation process, internal organization structure, and administrative system. This study follows conceptualization adopted by Youndat et al. (2004) and Wright et al. (2001). This study focuses on intellectual capital as a multi-dimension construct identified by three components (human, social, and organization capital).

The concept of corporate culture has its roots in studies conducted by Deal and Kennedy (1982) and Peter and Waterman (1982). Corporate culture or organization culture is described as a set of values, beliefs, assumptions, and symbols that define the way in which a firm drives its business (Peter \& Waterman, 1982). Denison and Mishra (1995) defined corporate culture as a set of values, beliefs, behaviour, and sound patterns from the core identity of the organization. According to Hofstede (1991), culture represents the collective programming of the mind which distinguishes members of one organization from another. Based on the above definitions, Hofstede (1991) and Baron and Walters (1994) agree with the assertion that culture bestows a distinct identity to organization members and is congruent with cognitive perspective advanced by Sackman (1991) that focuses on shared meaning.

In their effort to study culture, scholars have provided different frameworks to make it easier to operationalize. Schein (1992) identified power, role, achievement, and support while Handy's (1993), classification included role, task, supportive and power culture. A common theme in these classifications is that a strong culture reflects values, beliefs, and norms that are widely shared and internalized by people. Hofsede (1991) and Aycan, Kanungo, Mendonca, Yu, Deller, Stahl, and Kurshid (2000) classified culture as either employee-oriented or task-oriented culture was adopted in the current study. Employee-oriented culture is concerned with employee's well bring characterized by participation and teamwork. The task-oriented assumption was characterized along three dimension: task goal, task orientation, and competitive orientation. Schneider (1994) argues that collaboration culture emphasizes teamwork, partnership, and cooperation. In the early 1990s, teamwork was a prevalent issue and has become a common practice to most organizations. An emergent theme is that teamwork leads to versatility, adaptability, and fostering of individual talent. In addition, employees feel a sense of ownership and pride towards the organization they work in. As noted by Hofsede (1991), collectivist culture is more likely to accept team-based work arrangements.

Hofsede's (1991) task-oriented culture is similar to Schneider's (1994) control culture which was characterized by hierarchy, centralized, goal definition and emphasized on reward, punishment, and formal 
systems. Aycan et al. (2000) classified task-oriented culture that replicated Hofsede's (1991) dimension of process-result oriented and pragmatic-normative orientation. The task-oriented culture is formalized, observes top-down communication, and requires employees to set procedures set down. This culture is more result-oriented and has little concern for employee's welfare in the organization. Peter and Waterman's (1982) study supports that strong cultures are more result-oriented. While the employee-oriented culture and task-oriented culture differ in relation to their assumptions, Aycan et al. (2000) noted that organizations are a combination of the two sets of cultural orientation, but one type of culture will be more dominant. In support of this argument, Pfeffer (1994) postulated that successful firms have culture that supports both value and contributions of their employees.

\section{Corporate Performance}

The debate on performance measures has been a domain of interest for academicians and practitioners. Richard, Devinney, Yip, and Johnson (2009) note that organization performance is the most widely used dependent variable in any area of management, though it remains vague and loosely defined. In its simplest term, performance relates to how organization achieves its stated goals and objectives. Whereas many studies have focused on financial measures which have been criticized as lagging, backward looking, and short-term indicators considered in managing performance effectively (Ittner \& Larcker, 1998). The argument is consistent with Bontis (2001) who asserts that traditional financial measures such as profit and loss statements and capital expenditure reports are inadequate for strategic decision making.

The growing importance of satisfying stakeholder's requirement has seen the development of the Balance Scorecard (BSC) which focuses on financial measure and non-financial measures (Kaplan \& Norton, 1992; 1996) and focuses on satisfying different stakeholders. Therefore, the study draws upon the notion of BSC as an alternative to traditional financial measures. Furthermore, corporate performance in quoted firms is complex and multi-dimensional and the achievement of listed firms is typically judged by multiple constituencies such as shareholders, investors, and general public. The different interests of the various groups influence performance and require that managers review performance in several areas simultaneously (Kaplan \& Norton, 1992).

\section{Intellectual Capital and Corporate Performance}

The concept of intellectual capital continues to interest academics and practitioners alike given the potential to affect competitive advantage and corporate performance. This recognition has led to numerous researches from different research settings. Riahi-Belkouli (2003) examined the linear relationship between intellectual capital and performance of multi-national organization in the USA. The study revealed a positive and significant relationship. The use of trademark application as the only component of intellectual capital, contradicts the assertion of Marr, Schiuman, and Neely (2004) that intellectual consists of human capital, social capital, and organizational capital (Kariuki et al., 2014). In addition, the study did not examine other factors that moderate or mediate the relationship.

Firer and Williams (2003) in a study of public listed companies in South Africa failed and found a negative relationship. Similar to Riahi-Belkouli (2003), the population consisted of a homogeneous sample of industries that extensively relied on intellectual capital. The study did not incorporate non-financial measures of performance or other factors that affect the relationship. Shabarati, Jawad, and Bontis (2010) in their study on pharmaceutical companies in Jordan reported a positive relationship on isolated effect of intellectual capital 
components and performance. Similarly, Ngari, Kamau, and Gichira's (2011) study on Kenya pharmaceutical companies, demonstrated that isolated effect of intellectual capital components had positive effect on performance. The studies relied on population that was homogeneous and examined only financial measures of performance. A study conducted in Malaysia by Bontis, Keow, and Richardson (2000) on the interrelationships between human, structural, and customer capital in service and non-service industries found that relationship between human capital and structural capital was positive in non-service industry but not significant in service industries. Similar results by Amedieu and Vivian's (2010) study on the impact of intangible capital on financial and commercial performance on French wine industry, revealed a negative relationship between intangible capital and positive relationship on commercial performance.

In their study, Youndat et al. (2004) adopted a configuration approach to examine how human, social, and organization capital impact on financial returns and Tobin $q$. The general finding from this study was that organization with high intellectual capital outperforms those with low profile of intellectual capital with regard to both finance returns and Tobin $q$. The study failed to include non-financial measures of performance and other factors that affect the relationship. Equally, Cabrita and Bontis (2008) examined interrelationship and interaction of intellectual capital components and business performance. Their study revealed a positive and significant relationship between intellectual capital and corporate performance. They recommended that future

studies should incorporate corporate culture as moderating variable and take into account objective measures of performance. Despite a critical assessment of combined effect of the relationship between intellectual capital components and corporate performance, the studies did not examine other variables such as moderating and mediating variables.

Preceding discussion reveals that previous studies have not addressed the process in which intellectual capital leads to performance. Becker and Gerhart (1996, p. 781) in their review of human resources practices and organization performance concluded that "the mechanisms by which human resource decision creates and sustains value are complicated and not well understood". This assertion agrees with Boudreau and Ramstad (1998) who acknowledged that SHRM depicts the complex manner in which human resource management creates firm value through a series of intervening or linked constructs which most empirical studies have not tested. Drawing from the foregoing studies, the current research proposes that intellectual capital influences corporate performance.

$\mathrm{H}_{1}$ : Intellectual capital has a significant influence on corporate performance.

\section{Intellectual Capital, Corporate Culture, and Corporate Performance}

The influence of intellectual capital and corporate performance remains widely studied in both SHRM and strategic management. While ample empirical evidence exists to suggest an array of relationship, new debates have emerged amongst scholars. The debates do not only present reasons for conflicting results but also present avenue for new research. Drawing upon the concept of inner environment, Ittner and Larcker (1998) propose hat instead of assuming that intellectual capital has a direct influence on organizational performance, the effect of intellectual capital can be contingent upon conditions inner environment that can either amplify or reduce the relationship. Rikowski (2007) argues that intellectual capital requires management attention to a set of organizational attributes including organizational culture, leadership, structure, and rewards. The role of these factors lies in creating an organization environment conducive to effective knowledge management process. He points that the relationship between intellectual capital and corporate culture has not been explored in depth in a 
coherent manner, implying that there is need for more research on moderating effect of corporate culture. Musheref (2014) posits that view of whether corporate culture is an asset or liability depends on management subscription to its crucial role. This implies that corporate culture can either be recognized as one of the most important enablers or inhibitors of intellectual capital.

Cabrita and Bontis's (2008) study on interrelationship and interaction of intellectual capital components and business performance indicated a positive and significant relationship. They recommended that future studies should incorporate corporate culture as moderating variable. This view is supported by Chaminde and Johnson (2003) that corporate culture moderates the relationship between intellectual capital and corporate performance. Osoro's (2013) study on intangible assets and performance of firms listed on NSE established that corporate culture had no moderating effect on the relationship between intellectual capital and performance. In a different setting, Musheref (2014) studied the moderating role of corporate culture on the relationship between intellectual capital and business performance in Iraq and established that corporate culture moderates the relationship between intellectual capital and business performance. Based on these findings, the current study proposed that corporate culture moderates the relationship between intellectual capital and corporate performance.

$\mathrm{H}_{2}$ : Corporate culture moderates the relationship between intellectual capital and corporate performance.

\section{Conceptual Framework}

The conceptual framework discusses the relationship between the study variables. In the schematic diagram, the direct influence of intellectual capital on corporate performance forms the basis of the study $\left(\mathrm{H}_{1}\right)$. In line with theoretical and empirical literature, the study proposed that corporate culture moderates the relationship between intellectual capital and corporate performance $\left(\mathrm{H}_{2}\right)$. The interrelationship forming the bases of conceptual model is presented in Figure 1.

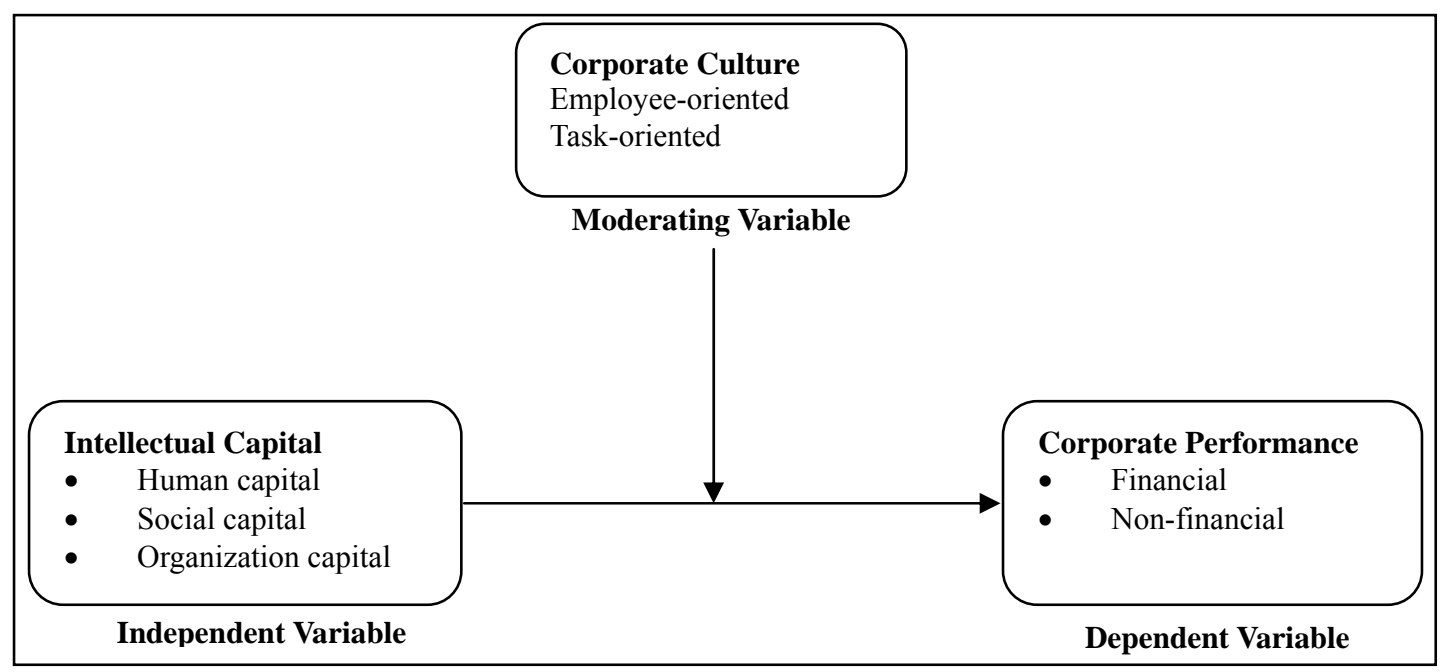

Figure 1. Conceptual framework.

\section{Research Methodology}

This section describes the research methodology used in the study. Specifically, it gives a detailed description of the research philosophy, research design, study population, data instruments, and data analysis.

\section{Philosophy of the Study}


This study was consistent with the positivist paradigm. First, the study was theory-based and conceptual framework guiding the study was developed through an exhaustive review of literature. In addition, the research hypotheses were subjected to empirical testing using statistical techniques such as regression analysis.

Creswell (2003) cited survey as frequently used research under the positivism approach. The study adopted a cross sectional survey design which involved collecting data from the phenomenon at the time of the study and allowed conclusions to be drawn. The cross-sectional approach represents a snapshot of one point in time across a large number of response units.

\section{Population of the Study}

The population of the study comprised all firms listed at the NSE for a four-year period from 2009 to 2012. According to the NSE Handbook (2012-2013), the total number of listed companies at the bourse was 62. In 2009 there were 55 companies, and of the 55 companies listed before 2009, five companies were ineligible for the study as preliminary review of their records revealed that they did not have the required data for the study. A census survey of the companies was carried out since the population was very small. In total 50 companies were studied.

\section{Instrument and Procedures}

The study used both primary and secondary data. Secondary data relating to financial performance were obtained from the listed companies audited accounts, NSE handbooks, and CMA yearly reports. The data included ROA, ROE and Dividend Yield as an average of four years' performance from 2009 to 2012. Primary data were obtained through a survey questionnaire developed from a wide review of literature. The questionnaire consisted of four sections. Section 1 sought general information pertaining to the respondents. Section 2, 3, and 4 addressed intellectual capital, corporate culture, and non-financial measures of performance respectively, designed on a five point Likert-type scale.

Several techniques were used in the administration of the questionnaire. First, the researcher made telephone calls and visits to the targeted companies to facilitate communication. After initial contact with the firms, appointments dates were agreed with the respondents and the questionnaires were personally delivered to the human resource managers. A description of the questionnaire items was provided either orally or through a telephone call. Extensive follow-up procedures were undertaken which included telephone calls, e-mails, and follow up visits to respective companies to enhance the response rate.

The respondent was the human resource manager. The choice of the respondents is consistent with studies by Cabrita and Bontis (2008) and Shabarati et al. (2010) who argued that organization characteristics measured were known to selected members in upper echelons, thus they were likely to provide more reliable information. The view of key informant is widely used in human resource management studies (Huselid, Jackson, \& Schuler, 1997; Cabrita \& Bontis, 2008). The targeted respondents were deemed knowledgeable about issues under investigation for which they are directly responsible.

\section{Data Analysis}

The results were first tested for reliability using Cronbach alpha and presented in Table 1. The Variance Inflation Factor (VIF) was included in all the regression analysis to check for multi-collinearity. The VIF for this study ranged from 1.112 to 2.484 indicating no problem of multi-collinearity between the study variables. The study utilized both financial and non-financial measures, and since it was not possible to combine both, the 
researcher divided the hypotheses into two categories: financial and non-financial. Separate analyses were performed for non-financial and financial indicators of organizational performance respectively. Hypotheses were tested one at a time, beginning with non-financial measures and financial measures respectively.

In order to test the study's hypotheses and their effect on organizational performance, a series of regression analysis were performed. Hypothesis one involved testing the influence of intellectual capital on corporate performance. The hypothesis was tested using simple regression for each of the influence of intellectual capital on corporate performance. A multiple regression analysis was performed for the variable of intellectual capital on corporate performance.

Hypothesis two involved testing the moderating effect of corporate culture on the relationship between intellectual capital and corporate performance. Hierarchical regression analysis was used for moderation using three steps. The first step involved testing the relationship between intellectual capital and corporate performance. The second step involved standardizing the independent variable (intellectual capital) and moderating variable (corporate culture). The third step involved creating an interaction term as a product of standardized independent variable*standardized moderating variable that is included in the model for testing the influence on corporate performance. Moderation is assumed to take place if the interaction term in step three is statistically significant.

\section{Results of Research}

The instruments were first tested for reliability. Intellectual capital had 17 items and reliability of Cronbach alpha 0.861 . The constructs of human capital had a Cronbach alpha of 0.774 , social capital had a reliability of 0.844 , and organization capital 0.948 . This implies that all constructs of intellectual capital had acceptable reliability.

Corporate culture the moderating variable had the lowest reliability of 0.546 , constructs of employee-oriented culture had 0.849 , and task-oriented culture was 0.262 which fell below the recommended threshold of 0.70 by Nunnaly (1978). Nunnaly (1978) recommended that only constructs with threshold of 0.7 and above should be considered for further analysis. After exclusion of variables with a non-significant value (task-oriented culture) the value of Cronbach's alpha increased. Non-financial performance was measured using 12 items and had a reliability of 0.877 and constructs of customer service 0.741 , internal business process 0.677 and learning and growth 0.916 .

\section{Hypothesis Testing}

Hypothesis one proposed that intellectual capital significantly influences on corporate performance. Four models were formulated to test for hypothesis so as to ascertain the individual effect of each construct of intellectual capital (human capital, social capital, and organizational capital). A multiple regression analysis was performed to assess the impact of intellectual capital on performance. Simple regression analysis was performed for Model 1 through three representing sub-hypotheses $1_{\mathrm{a}}, 1_{\mathrm{b}}$, and $1_{\mathrm{c}}$ to test the effect of each predictor variable on non-financial performance. The sub-hypotheses were stated as follows.

$\mathrm{H}_{1 \mathrm{a}}$ : Human capital significantly influences non-financial performance.

$\mathrm{H}_{1 \mathrm{~b}}$ : Social capital significantly influences non-financial performance.

$\mathrm{H}_{1 \mathrm{c}}$ : Organization capital significantly influences non-financial performance.

The summarized results for the sub-hypothesis are presented in Table 1. 
Table 1

Summary of Regression Results for Individual Influence of Human (Capital, Social Capital and Organization Capital on Non-financial Performance)

\begin{tabular}{|c|c|c|c|c|c|c|c|c|}
\hline \multirow[t]{2}{*}{ Model } & \multicolumn{2}{|c|}{ Model 1} & \multicolumn{2}{|c|}{ Model 2} & \multicolumn{2}{|c|}{ Model 3} & \multicolumn{2}{|c|}{ Model 4} \\
\hline & $\beta$ & $t$ & $\beta$ & $t$ & $\beta$ & $t$ & $\beta$ & $t$ \\
\hline Constant & 0.298 & 2.069 & 0.353 & 4.068 & 0.472 & 7.56 & 0.162 & 1.260 \\
\hline Human capital & $0.477^{*}$ & 2.529 & & & & & 0.186 & 0.931 \\
\hline Social capital & & & $0.459 *$ & 3.165 & & & $0.304 *$ & 2.045 \\
\hline Organizational capital & & & & & $0.251 *$ & 3.162 & $0.206^{*}$ & 2.882 \\
\hline $\mathrm{R}^{2}$ & 0.167 & & 0.290 & & & 0.238 & & 0.452 \\
\hline $\mathrm{F}$ & $6.398 *$ & & $13.067 *$ & & & $9.95^{*}$ & & $8.243^{*}$ \\
\hline
\end{tabular}

Note. * Significance 0.05 level.

The findings in Model 1 show that human capital explained $16.7 \%$ of the variance in non-financial performance $\left(\mathrm{R}^{2}=0.167\right)$. The results suggest a statistically significant influence of human capital on non-financial performance with the overall model $(\mathrm{F}=6.98, p<0.05)$ and individual parameters $(\beta=0.477, t=$ $2.529, p<0.05)$ were statistically significant. Model 2 on social capital accounted for $29.0 \%$ of variation in non-financial performance $\left(\mathrm{R}^{2}=0.290\right)$. The overall model was statistically significant $(\mathrm{F}=13.067, p<0.05)$ and the individual variables were statistically significant $(\beta=0.459, t=3.615, p<0.05)$. Model 3 on organization capital accounted for $23.8 \%$ of variance in non-financial performance $\left(R^{2}=0.238\right)$. The overall model was statistically significant $(\mathrm{F}=9.995, p<0.05)$ and individual variables were statistically significant $(\beta$ $=0.251, t=3.162, p<0.05$ ). The results suggest that each of the constructs of intellectual capital significantly contributes to non-financial performance. However, the models are generally weak.

Model 4 is based on the proposition that the combined effect of intellectual capital constructs has a greater influence on corporate performance. The regression results in Model 4 show that intellectual capital accounted for $45.2 \%$ of variance in non-financial performance $\left(\mathrm{R}^{2}=0.452\right)$. The overall model was statistically significant $(\mathrm{F}=8.243, p<0.05)$ and of the three constructs, social capital $(\beta=0.304, t=2.045, p<0.05)$ and organizational capital was statistically significant $(\beta=0.206, t=2.882, p<0.05)$, whereas human capital was not significant $(\beta=0.186, t=0.931, p>0.05)$. The results provide sufficient evidence to support the proposition that the combined effect of intellectual capital on non-financial performance is greater than individual effect of human capital, social capital, and organization capital. Similar tests were performed on financial measures of performance collected from secondary sources. The results are presented in Table 2 .

Table 2

Summary of Regression Results for Individual Influence of Human (Capital, Social Capital and Organization Capital on Financial Performance (ROA))

\begin{tabular}{|c|c|c|c|c|c|c|c|c|}
\hline \multirow[t]{2}{*}{ Model } & \multicolumn{2}{|c|}{ Model 1} & \multicolumn{2}{|l|}{ Model 2} & \multicolumn{2}{|c|}{ Model 3} & \multicolumn{2}{|c|}{ Model 4} \\
\hline & $\beta$ & $t$ & $\beta$ & $t$ & $\beta$ & $t$ & $\beta$ & $t$ \\
\hline Constant & -0.021 & -0.346 & -0.019 & -0.494 & 0.072 & $2.541^{*}$ & -0.005 & -0.005 \\
\hline Human capital & 0.106 & 1.317 & & & & & 0.007 & 0.070 \\
\hline Social capital & & & $-0.343 *$ & $2.065^{*}$ & & & 0.126 & 0.074 \\
\hline Organizational capital & & & & & -0.018 & -0.488 & -0.034 & 0.030 \\
\hline $\mathrm{R}^{2}$ & 0.051 & & 0.118 & & 0.007 & & 0.0144 & \\
\hline $\mathrm{F}$ & 1.735 & & $4.263^{*}$ & & 0.238 & & 1.684 & \\
\hline
\end{tabular}

Note. * Significance 0.05 level. 
The findings in all the models show insignificant relationship with exception of social capital in Model 2 which shows that social capital explained $11.8 \%$ of the variance on ROA $\left(\mathrm{R}^{2}=0.167\right)$. The results suggest a statistically significant influence of social capital on ROA with the overall model $(\mathrm{F}=4.263, p<0.05)$ and individual parameters $(\beta=0.343, t=2.065, p<0.05)$ were statistically significant. The results on ROE and Divided Yield were all insignificant and thus not included in the study.

Hypothesis 3 tested the moderating effect of corporate culture on the relationship between intellectual capital and corporate performance. Hierarchical regression analysis was used to test the relationship as presented in Table 3.

Table 3

Regression Results for Moderating Effect of Corporate Culture on Relationship Between Intellectual Capital and Non-financial Performance

\begin{tabular}{lllllll}
\hline Variables & \multicolumn{2}{c}{ Step 1 } & \multicolumn{2}{c}{ Step 2 } & \multicolumn{2}{c}{ Step 3 } \\
\hline & $\beta$ & $t$ & $\beta$ & $t$ & $\beta$ & $t$ \\
\hline Constant & 0.660 & 40.979 & 0.660 & 48.302 & 0.653 & 40.561 \\
Intellectual capital & 0.079 & 4.839 & & & & \\
Z-intellectual capital & & & 0.045 & 2.735 & $0.041^{*}$ & 2.289 \\
Z-employee-oriented culture & & & 0.061 & 3.668 & $0.061^{*}$ & 3.668 \\
Z-intellectual capital*Z-employee-oriented culture & & & & & 0.013 & 0.818 \\
$\mathrm{R}^{2}$ & 0.423 & & 0.597 & & 0.606 & \\
Adjusted R $^{2}$ & 0.404 & & 0.571 & & 0.561 & \\
$\mathrm{R}^{2}$ change & 0.423 & & 0.175 & & 0.009 & \\
$\mathrm{~F}$ & $23.411^{*}$ & & $22.991^{*}$ & & & \\
\hline
\end{tabular}

Note. * Significance 0.05 level.

The results in step 1 show that intellectual capital alone accounted for $42.3 \%$ of the variance in non-financial performance $\left(\mathrm{R}^{2}=0.423, p<0.05\right)$. The results suggest a statistically significant influence of intellectual capital on non-financial performance $(\mathrm{F}=23.411, p<0.05)$ and individual parameters $(\beta=0.477, t$ $=2.529, p<0.05$ ) were statistically significant.

In step 2, the results show that the standardized values of intellectual capital and employee-oriented culture accounted for $59.7 \%$ of the variance in non-financial performance $\left(\mathrm{R}^{2}=0.597, p<0.05\right)$. The $\mathrm{R}^{2}$ in step 2 is higher than step 1 by $0.175\left(\mathrm{R}^{2}\right.$ change $\left.=0.175\right)$. Results in step 2 indicate that the overall model was significant $(\mathrm{F}=22.991, p<0.05)$ standardized values of intellectual capital $(\beta=0.045, t=2.735, p<0.05)$ and employee-oriented culture $(\beta=0.061, t=3.668, p<0.05)$ had a significant contribution to non-financial performance.

In step 3, the interaction term was formed as a product of standardized score intellectual capital*standardized score employee-oriented culture and entered into the model. The interaction term accounted for $60.6 \%$ of variance in non-financial performance $\left(\mathrm{R}^{2}=0.606, p<0.05\right)$. The results in step 3 show that when interaction term was entered into the model, it added, albeit small significantly to non-financial performance as the variation increased from 0.597 to $0.606\left(\mathrm{R}^{2}\right.$ change $\left.=0.009\right)$. The overall model remained statistically significant $(\mathrm{F}=15.386, p<0.05)$. In the third step when the interaction term was added in the model, the regression coefficient of the interaction term was statistically insignificant $(\beta=0.013, t=0.818, p>$ $0.05)$, hence, the criterion for step 3 was not met. The results thus indicated insufficient evidence to support the 
hypothesis that the influence of intellectual capital on non-financial performance is moderated by employee-oriented culture.

The results on financial measures of performance that is ROA, ROE, and Dividend Yield were all insignificant.

\section{Discussion}

Based on this assumption, there was need to test the influence of each component on performance. Three sub-hypotheses were formulated and simple regression analysis was performed. Intellectual capital was shown to have a higher explanatory power $\left(\mathrm{R}^{2}=0.452\right)$. Compared to constructs of human capital $\left(\mathrm{R}^{2}=0.167, \mathrm{~F}=\right.$ 6.398, $\beta=0.477, p<0.05)$, social capital $\left(\mathrm{R}^{2}=0.290, \mathrm{~F}=13.06, \beta=0.459, p<0.05\right)$ and organization capital $\left(\mathrm{R}^{2}=0.238, \mathrm{~F}=9.95, \beta=0.259, p<0.05\right)$ had a statistically significant relationship with non-financial performance. In addition, the results of multiple regression analysis on the influence of intellectual capital on corporate performance show that the overall model was statistically significant $(\mathrm{F}=8.243, p<0.05)$ and of the three constructs, social capital $(\beta=0.304, t=2.045, p<0.05)$ and organizational capital was statistically significant $(\beta=0.206, t=2.882, p<0.05)$, whereas human capital was not significant $(\beta=0.186, \mathrm{t}=0.931, p>$ $0.05)$. The results suggest that the combined effect of intellectual capital was greater than the individual influence of human capital, social capital, and organization capital on non-financial performance. The findings are consistent with observations made by Becker and Gerhart (1996) that synergetic effect rather than independent practices leads to competitive advantage.

Findings on financial measures of performance, ROA, ROE, and Divided Yield presented insignificant results with exception of social capital and ROA. Social capital explained $11.8 \%$ of the variance on $\mathrm{ROA}\left(\mathrm{R}^{2}=\right.$ 0.167). The results suggest a statistically significant influence of social capital on ROA with the overall model $(\mathrm{F}=4.263, p<0.05)$ and individual parameters $(\beta=0.343, t=2.065, p<0.05)$ were statistically significant. The study findings are in line with other findings that reported that financial measures of performance in their research focusing on firms listed on Nairobi Securities Exchange reported mixed results (Ongore, 2008; Letting, 2011; Osoro, 2013) reported mixed results on ROE, ROA, and Dividend Yield.

The results of the study provide support that there is a statistically significant relationship between intellectual capital and non-financial performance. These findings are consistent to a greater extent with previous findings of Youndat et al. (2004). The researchers established that organizations with high intellectual capital outperform those with low profile of intellectual capital. Similarly, a study by Cabrita and Bontis (2008) on the banking sector in Portugal established a positive significant relationship between intellectual capital and perceptual measures of performance. In addition the results are in line with Fire and Williams's (2003) findings on the relationship between intellectual capital and performance, revealing a negative relationship between intellectual capital (structural, physical, and human capital) and performance of 75 publicly listed companies in South Africa. Their study is in line with the findings of the current study that indicated no significant relationship between intellectual capital ROE and Dividend Yield.

The results of the study differ from Riahi-Belkouli (2003) who studied relationship between intellectual capital and corporate performance of multinational firms in the United States and found a positive and significant relationship on financial measures of performance. A major difference between the study by Riahi-Belkouli (2003) and the current study is that their study focused on financial measures of performance, while the current study focused on both financial and non-financial measures. 
The findings of this study support the recent argument of some organization and human resource management scholars regarding the importance of intellectual capital to firm performance (Bontis, 1998; Cabrita \& Bontis, 2008). Drawing on theoretical insights of resource-based view of the firm, the study complements and extends the arguments that competitive advantage can be attributed to unique resources particularly intangible ones when they are combined or integrated. This finding lends support that combined effect of intellectual components has a greater effect on corporate performance than isolated effect of individual components. The results suggest that it would be difficult for a competitor to imitate the three components compared to a single component. The regression results on composite index of intellectual capital and isolated effect of human, social capital, and organization were reflective of this assertion. The results further reaffirmed the position of Stewart (1997) who asserted that the three constructs affect each other and deficiency in any of the factors can affect overall firm performance.

\section{Corporate Culture Moderates the Relationship Between Intellectual Capital and Corporate Performance}

Literature relating to the link between intellectual capital, corporate culture, and corporate performance is limited, it has been argued that corporate culture can contribute or inhibit intellectual capital management. Following the proposition of Chaminade and Johanson (2003) and Cabrita and Bontis (2008), the study hypothesized corporate culture as a moderating variable. They recommended that scholars should investigate the phenomenon of organization culture in different cultural contexts particularly in non-western nations. The results of the study did not provide sufficient evidence to support moderating effect of corporate culture, on the relationship between intellectual capital and non-financial performance and financial performance (ROA, ROE, and Dividend Yield). The results of the current study are fairly comparable to other empirical studies that did not establish the moderating effect of corporate culture. Kandie (2009) established that organization culture did not provide significant moderating effect on the link between strategy and performance of small and medium enterprises in Kenya. Similar to the current study, the research proposed corporate culture as a moderator. A similar result by Mulabe (2013) established that organization culture did not moderate the relationship between human resource strategic orientation and employee outcome of State Corporation in Kenya.

The study contradicts Chaminde and Johnson's (2003) assertion that cultural diversity has a significant impact on intellectual capital development at both the firm and national level. The finding is inconsistent with Mutuku (2012) who established that involvement culture (empowerment, capacity development, and team-orientation) has a significant moderating effect on the relationship between top management team diversity and organizational performance in commercial banks in Kenya. Mutuku's (2012) findings differ from the current study because the study was conducted in a single industry while the focus of the current study is on different industries. The firms listed on Nairobi Securities Exchange are regulated by Capital Market Authority and thus have to adhere to stringent rules which are not within the control of the organization. Teamwork is encouraged and there is cooperation amongst the employees, decisions are made at the top and cascaded to the employees. This suggests that the role of employees is limited to that of executing orders from top management. Trust is an important element, and although employees seem to be moderately trusting to their colleagues (citizenship behaviour), the same may not apply to the top management.

The inconsistencies in the findings can also be explained by differences in conceptualization. Previous studies (Stewart, 1997; Edvinsson \& Malone, 1997; Bontis, 1998) have conceptualized culture as a construct of organization capital. Employee-oriented culture is thus supposed to provide a supporting mechanism in which human capital and social capital can be developed. 


\section{Conclusion}

The first objective of the current study was to determine the relationship between intellectual capital and corporate performance. This was achieved by ascertaining whether the combined effect measured as a composite index of predictor variables had a greater effect on performance compared to the individual predictor variables (human capital, social capital, and organization capital) on corporate performance. The results revealed that there was a statistically significant relationship between intellectual capital and non-financial performance. The findings revealed that there was no relationship between intellectual capital and financial measures of performance (ROA, ROE, and Dividend yield).

The second objective was to establish the moderating effect of corporate culture on the relationship between intellectual capital and corporate performance. Corporate culture was operationalized as task-oriented culture and employee-oriented culture. However, preliminary tests revealed the reliability of task-oriented culture $(\alpha=0.261)$ was below the 0.7 threshold recommended by Nunnaly (1978). The results from hierarchical regression analysis reveal that the interaction term formed as a product of standardized intellectual capital*standardized employee-oriented culture was insignificant, thus failing to provide sufficient evidence to support the moderating effect of employee-oriented culture on the relationship between intellectual capital and non-financial performances and financial measures of performance.

\section{Implication}

The study demonstrates importance of the influence of intellectual capital on non-financial performance of firms listed on Nairobi Securities Exchange. The results show that interplay among human capital, social capital, and organization capital is important for firms listed on Nairobi Securities Exchange and that the firms should nurture the employees into sharing their knowledge by creating internal and external networks and also creating support system within the organization to retain the knowledge. In addition, the study confirmed that intangible assets provide a superior explanation of performance than isolated effect of individual variables. The strength of different combination has been highlighted and practitioners have an empirical basis to pursue.

The results of this study did not support the moderating effect of employee-oriented culture. The objective on the moderating effect of employee-oriented culture on the relationship between intellectual capital and performance did not predict the resource-based theory proposition that corporate culture is a source of competitive advantage because it cannot be transferred from one organization to another due to its historical conditions and social complexity.

\section{Suggestion of Further Research}

The need to develop a better understanding of the results suggests avenues for future research that are worthwhile. First, Becker and Gerhart (1996) advocate that broader, more qualitative methods are needed to study phenomenon of human resource management utilizing multiple sources of information and respondents. Thus, future studies should take into account more respondents to avoid potential biases that arise from key informant methodology. The study population was small, and it would be appropriate that future studies should include more respondents or study different settings like the public sector.

The study examined the impact of return on assets, return on equity and dividend yield on study variables. Return on assets provided partial support for the hypotheses while return on equity and dividend yielded had insignificant results. It may be useful that future researchers re-examine this further by using other market based measures such as Tobin $q$ and share price. 
The conceptualization of task-oriented culture should provide a basis for further study. The task-oriented culture raised reliability concerns. An extension of moderating effect of task-oriented culture in future research could provide a better understanding of factors that moderate the influence of intellectual capital on performance. Future researchers could consider rewording the concept of culture so as to detect contradictory opinion often inherent in Likert-type scale.

\section{References}

Amadieu, P., \& Vivian, J. (2010). Intangible effort and performance: The case of French wine industry. Agribusiness Journal, 2, 280-306.

Aycan, Z., Kanungo, R., Mendonca, M., Yu, K., Deller, J., Stahl, G., \& Kurshid, A. (2000). Impact of culture on human resource management practices: A 10 country comparison. An International Review: Applied Journal of Psychology, 49(1), $192-221$.

Baron, A., \& Walters, M. (1994). The culture factor corporate and international perspective. London: Institute of Personnel and Development.

Becker, G. S. (1993). Human capital: A theoretical and empirical analysis with special reference to education. Economic and Industrial Democracy, 27(2), 240-260.

Becker, B. E., \& Gerhart, B. (1996). Human resources and organization performance: Progress and prospects. Academy of Management Journal, 39, 779-801.

Bontis, N. (1996). There's a price on your head: Managing intellectual capital strategically. Business Quarterly, 40-47.

Bontis, N. (1998). Intellectual capital: An exploratory study that develops measures and models. Management Decision Journal, 36(2), 63-76.

Bontis, N. (1999). Managing organizational knowledge by diagnosing intellectual capital: Framing and advancing the state of the field. International Journal of Technology Management, 18(5/6/7/8), 433-462.

Bontis, N. (2001). Assessing knowledge assets: A review of the models used to measure intellectual capital. International Journal of Management Review, 3(1), 41-60.

Bontis, N., Keow, W., \& Richardson, S. (2000). Intellectual capital and the nature of business in Malaysia. Journal of Intellectual Capital, 1(1), 85-100.

Boudreau, J., \& Ramstad, P. (1998). Human resource metrics: Can measures be strategic? CAHRS Working Paper Series 123.

Cabrita, R., \& Bontis, N. (2008). Intellectual capital and business performance in Portuguese banking industry. International Journal of Technology Management, 43, 212-237.

Chaminade, C., \& Johanson, J. (2003). Can guidelines for intellectual capital management and reporting be considered without addressing cultural differences? Journal of Intellectual Capital, 437-455.

Child, J. (1981). Culture, contingency and capitalism in the cross-national study of organizations. Research in Organization Behavior, 3, 303-356.

Creswell, J. W. (2003). Research design: Qualitative, quantitative and mixed methods approaches (2nd ed.). USA, Thousand Oaks: Sage Publications.

Deal, T. E., \& Kennedy, A. A. (1982). Corporate cultures: The rites and rituals of corporate life. Readings, MA: Wesley Publishing Company.

Denison, D. R., \& Mishra, A. K. (1995). Towards a theory of organization culture and effectiveness. Organization Science, 6(2), 204-223.

Edvinsson, L., \& Malone, M. S. (1997). Intellectual capital: Realizing your company’s true value by finding its hidden roots. New York: Harper Business.

Firer, S., \& Williams, S. (2003). Intellectual capital and traditional measures of corporate performance. Journal of Intellectual Capital, 4(3), 348-360.

Hair, J. F., Anderson, R. E., Tatham, R. L., \& Black, W. C. (2006). Multivariate data analysis (5th ed.). Upper Sadddle River, NJ: Prentice Hall.

Handy, C. (1993). Understanding organizations (4th ed.). London-UK: Penguin Books Ltd.

Hatch, W. N., \& Dyer, H. J. (2004). Human Capital and learning as a source of competitive advantage. Strategic Management Journal, 25, 1155-1178.

Hitt, M. A., Bierman L., Shimizu, K., \& Kochar, R. (2001). Direct and moderating effects of human capital on strategy and performance in professional service firms: A resource-based perspective. Academy of Management Journal, 44(1), 13-28. 
Hofstede, G. (1991). Culture and organizations. London: McGraw-Hill.

Huang, C. J., \& Liu, C. J. (2005). Exploration for the relationship between innovation, IT and performance. Journal of Intellectual Capital, 6(2), 237-252.

Huselid, M. A., Jackson, S. E., \& Schuler, R. S. (1997). Technical and strategic human resource management effectiveness as determinants of firm performance. Academy of Management Journal, 40(1), 171-188.

Ittner, C., \& Larcker, D. (1998). Are non-financial measures leading indicators of financial performance? An analysis of customer satisfaction. Journal of Accounting Research, 36, 1-35.

Kaplan, R., \& Norton, D. (1992). The balance scorecard. Measures that drives performance. Harvard Business Review, 70, 71-79.

Kaplan, R., \& Norton, D. (1996). The balance scorecard. Translating strategy into action. Boston: Harvard Business School Press.

Kandie, P. Y. (2009). The link of organization's strategy and institutional factors on performance of small and medium enterprises in Kenya (Unpublished Ph.D. Thesis). School of Business, University of Nairobi.

Kariuki. (2014). Intellectual capital, corporate reputation, corporate culture and performance of firms listed on Nairobi Securities Exchange (Unpublished Ph.D. Thesis). School of Business, University of Nairobi.

Kariuki, A., K'Obonyo, P., \& Ogutu, M. (2014). Intellectual capital and organizational performance of firms listed on Nairobi Securities Exchange. DBA Africa Management Review.

K'Obonyo, P., \& Dimba, B. (2007). Influence of culture on strategic human resource management practices in multinational companies in Kenya: A critical literature review. http://www.strathmore.edu, September,14, 2012

Letting, N. K. (2011). Board of directors attributes, strategic decision-making and corporate performance of firms listed on the Nairobi Stock Exchange (Unpublished Ph.D. Thesis). School of Business, University of Nairobi.

Marr, B., Schiuman, G., \& Neely, A. (2004). The dynamics of value creation: Mapping your intellectual capital performance drivers. Journal of Intellectual capital, 5(2), 312-325.

Mulabe, J. K. (2013). Human resource strategic orientation, employee outcomes, organizational factors and performance of state corporations in Kenya (Unpublished Ph.D. Thesis). School of Business, University of Nairobi.

Musheref, A. M. (2014). The moderate role of organizational culture between intellectual capital and business performance: An empirical study in Iraq industry. Net Journal of Social Sciences, 2(3), 82-91.

Mutuku, C. M. (2012). Factors influencing relationship between top management team diversity and performance of commercial banks in Kenya (Unpublished Ph.D. Thesis). School of Business, University of Nairobi.

Nahapiet, J., \& Ghoshal, S. (1998). Social capital, intellectual capital and the organization advantage. Academy of Management Review, 23(2), 242-265.

Ngari, J. M., Kamau, J. N., \& Gichira, R. (2011). Relationship between intellectual capital accounting and financial performance: An empirical review of Kenya pharmaceutical companies. International Journal of Practice, 2(4), 21-35.

Nunnaly, J. (1978). Psychometric theory (2nd ed.). New York: McGraw Hill.

Nyambegera, S., Daniels K., \& Sparrow, P. (2001). Why fit doesn't always matter: The impact of human resource management on job involvement of Kenya employees. An International Review: Applied Psychology Journal, 5(1), 109-140.

OECD. (1998). Human capital investment. An international comparison. Paris: Organization for Economic Cooperation Centre for Educational Eesearch and Innovation.

Ongore, V. K. (2008). The effects of ownership structure, board effectiveness and managerial discretion on performance of listed companies (Unpublished Ph.D. Thesis). School of Business, University of Nairobi.

Osoro, M. K. (2013). Intangible assets, firm characteristics, competitive strategy and performance of companies listed at the Nairobi securities exchange (Unpublished Ph.D. Thesis). School of Business, University of Nairobi.

Peter, T., \& Waterman, R. (1982). In search of excellence: Lessons from America's best run companies. New York: Harper and Row.

Pfeffer, J. (1994). Competitive advantage through people: Unleashing the power of the workforce. Boston: Harvard Business School Press.

Riahi-Belkouli, A. (2003). Intellectual capital and firm performance of US multi-national firms: A study of resource-based and stakeholders view. Journal of Intellectual Capital, 4(2), 215-226.

Richard, P. J., Devinney, T. M., Yip, G. S., \& Johnson, G. (2009). Measuring organizational performance: Social behaviour and personality. An International Journal, 36(6), 827-840.

Rikowski, R. (2007). Knowledge management: Social, cultural and theoretical perspectives. Great Britain: Chados Publishing, Oxford Limited. 
Roos, J., \& Roos, G. (1997). Measuring your company's intellectual performance. Long Range Planning, 30(31), 413-436.

Roos, J., Roos, G., Dragonetti, N. C., \& Edvinsson, L. (1997). Intellectual capital: Navigator in the business landscape. London: Macmillan.

Sackman, S. (1991). Cultural knowledge in organizations. London: Sage Publications.

Schneider, W. E. (1994). The reengineering alternative a place for making your current work. Illinois: Irwin.

Schein, E. H. (1992). Organizational culture and leadership (1st ed.). San Francisco: Jossey-Bass.

Shabarati, A., Jawad, J., \& Bontis, N. (2010). Intellectual capital and business performance in pharmaceutical sector of Jordan. Management Decision Journal, 48(1), 105-131.

Stewart, T. A. (1997). Intellectual capital: The new wealth of organization. New York: Doubleday.

Wright, P. M., Dunford, B. B., \& Snell, S. A. (2001). Human resources and resource-based view of the firm. Journal of Management, 27(6), 701-721.

Youndat, M., Subramanian, M., \& Snell, S. (2004). Intellectual profiles: An examination of investment and returns. Journal of Management Studies, 41(2), 0022-238. 